\title{
Genetic parameters for weight gain and body measurements for Nile tilapias by random regression modeling ${ }^{1}$
}

\author{
Estimação de parâmetros genéticos para peso corporal, ganho em \\ peso e características morfométricas de tilápias do Nilo utilizando \\ modelos de regressão aleatória ${ }^{1}$
}

\author{
Ana Carolina Müller Conti ${ }^{*}$; Carlos Antonio Lopes de Oliveira ${ }^{3}$; \\ Elias Nunes Martins 3 ; Ricardo Pereira Ribeiro3; Annaiza Braga Bignardi4; \\ Emilia Paiva Porto ${ }^{5}$; Sheila Nogueira de Oliveira ${ }^{6}$
}

\begin{abstract}
The aim of the current study was to estimate the genetic parameters for weight gain and body measurements in the GIFT (Genetically Improved Farmed Tilapia) strain of Nile tilapia by random regression models. Several orders of Legendre polynomials were tested for random effects and modeled with 1, 3, 6 and 9 classes of residual variance. For the effects of permanent environmental and family, third-order polynomials were adjusted in all traits, as well as for the genetic effects of weight, weight gain, length and width. For genetic effects of height and head, fourth-order polynomials were required. To gain weight, height and head, the best model was one that considered the homogenous residual variance; however for width and weight, heterogeneous variance with 3 and 9 age classes was required, respectively. The highest heritability for weight was 0.34 at 240-311 days, and for weight gain it was 0.69 at 311 days. For head and length, the highest heritability was around 270 days at 0.27 and 0.21 , respectively. The highest heritability found for length was 0.20 at 254 days, 0.2 at 254 days for height, and for width the heritability was 0.54 at 311 days. Since the largest heritabilities were found for weight gain and width at 311 days, selection at these ages, based on these traits, would lead to greater genetic gains. Genetic correlations were higher between adjacent ages and, in general, selections at ages of less than 200 days did not lead to genetic gain correlated with traits at 300 days. The exception was for width, because high correlations were obtained between final and initial ages and the heritability was median in the majority of the period. Thus, selection based on the width at any age would lead to satisfactory genetic gain in this trait at the end of the growing season.
\end{abstract}

Key words: Strain, heritability, Legendre polynomials, longitudinal data

\footnotetext{
${ }^{1}$ Part of the thesis of the first author submitted to the Graduate Program in Animal Science from the State University of Maringá, UEM, as part of the requirements for obtaining the title of Doctor in Animal Production. Doctoral fellow of CNPq.

${ }^{2}$ Prof. of Animal Science, Federal University of Tocantins, UFT, Araguaína, TO, Brasil. E-mail: acmconti@uft.edu.br; acmconti@ hotmail.com

${ }^{3}$ Prof. of the Postgraduate Program in Animal Science, State University of Maringá, UEM, Maringá, PR, Brasil. E-mail: enmartins@ uem.br; rpribeiro@uem.br; caloliveira@uem.br

${ }^{4}$ Prof. of Animal Science, Grupo de Melhoramento Animal de Mato Grosso (GMAT), Federal University of Mato Grosso, UFMT, Rondonópolis, MG, Brasil. E-mail: annaizabb@hotmail.com

${ }^{5}$ Prof. of Veterinary Medicine, State University of Northern of Paraná, UENP, Bandeirantes, PR and doctoral student in the Postgraduate Program in Animal Science, State University of Maringá, UEM, Maringá, PR, Brasil. E-mail: emilia@uenp.edu.br

${ }^{6}$ Doctoral student in the Postgraduate Program in Animal Science, State University of Maringá, UEM, Maringá, PR, Brasil. E-mail: she_uem@hotmail.com

* Author for correspondence
} 


\title{
Resumo
}

\begin{abstract}
Objetivou-se estimar parâmetros genéticos para peso corporal, ganho em peso diário (GPD) e características morfométricas em tilápias do Nilo da variedade GIFT por meio de modelos de regressão aleatória. Foram testados modelos com ordens 2, 3 e 4 do polinômio de Legendre para o efeito genético aditivo, e ordens 2 e 3 para a idade, efeitos de ambiente permanente e de família. Testaram-se ainda modelos com variância residual homogênea e heterogênea. Para os efeitos de ambiente permanente e de família, os polinômios de terceira ordem proporcionaram melhor ajuste em todas as características, bem como para o efeito genético para peso, GPD, comprimento e largura. Para altura e tamanho de cabeça foram necessários polinômios de quarta ordem. Para ganho em peso, altura e cabeça o melhor modelo foi o que considerou variância residual homogênea para largura, variância heterogênea com três classes de idade e para peso e comprimento, variância heterogênea com nove classes de idade. A maior herdabilidade para peso foi 0,34 entre 240 e 311 dias, e para GPD foi 0,69 aos 311 dias. Para cabeça e comprimento a maior herdabilidade ocorreu aos 270 dias, sendo igual a 0,27 e 0,21 , respectivamente. A maior herdabilidade para o comprimento foi 0,20 aos 254 dias e para largura a maior herdabilidade foi 0,54 aos 311 dias. Uma vez que as maiores herdabilidades foram para GPD e largura aos 311 dias, a seleção baseada nestas características nestas idades levaria as maiores ganhos genéticos. As altas correlações genéticas entre idades superiores aos 200 dias de idade denotam a possibilidade de se utilizar como critério de seleção, idades pouco menores que as usuais (300 dias) sem diminuir o ganho genético. Como a largura apresentou herdabilidade de média magnitude na maior parte do período avaliado, a seleção baseada na largura em qualquer idade levaria a um ganho genético satisfatório nessa característica no final do período de cultivo.
\end{abstract}

Palavras-chave: Variedade GIFT, herdabilidade, polinômios de Legendre, dados longitudinais

\section{Introduction}

There is a demand for more protein foods with the increasing world population, and there is a search for foods with higher nutritional quality. Among these, fish stand out because they are considered an easily digestible, high protein, low calorie food and a good source of vitamins and minerals (SOUZA, 2001). However, according to Silva et al. (2009), the yield is suboptimal and, therefore, studies of species should be prioritized for improving animal performance.

In 2010, and throughout the previous year, there was a $7.5 \%$ increase in world fish production, with 60 million tons being produced worldwide. In the Americas, the largest producers are Chile, the United States and Brazil, with productions of 701.1, 495.5 and 479.4 thousand tons, respectively (UNITED NATIONS, 2012).

According to Ribeiro (2001), most species of tilapia have the most desirable characteristics of fish intended for commercial exploitation. This means they have good adaptability to varying conditions with have good feed conversion and weight gain and high roughness.

Tilapia breeding programs are interested in using animals showing rapid growth rates (RUTTEN; KOMEN; BOVENHIUS, 2005). In addition, the identification of animals with higher genetic merit for traits of economic importance is crucial to achieving genetic gains in breeding programs.

In tilapia breeding programs, the age at which to practice selection frequently is arbitrarily chosen, or it might be directly related to the age at market weight or the age at which the weight is optimal for reproduction (TURRA et al., 2012b). Therefore, the study of behavior in time of heritability and genetic correlations for traits of economic interest is extremely important to reduce the generation interval or decrease cost biometrics in tilapia breeding programs.

If a trait is measured several times during the life of an animal, the data generated are called longitudinal data and need to be analyzed considering there is a covariance structure between the various 
measurements. The most widely used models to analyze such data are repeatability (which admit a covariance of 1 between measurements), the multitrait models (where the observation at each age is considered a trait, and there is no assumption about the covariance between measurements; therefore, if there is large number of measurements the model becomes over parameterized) and random regression models (which admit covariance functions between measurements).

The estimation of genetic parameters by random regression models has advantages over the use of repeatability models or multi-trait models, since the first one allows the identification of the age at which the heritability is high enough to ensure the effectiveness of the program. In addition, knowledge about the trajectory of heritability could help predict the response to selection in the age range evaluated and, thus, predict costs of breeding programs based on alternative ages (TURRA et al., 2012a).

According to Lourenço, Maia and Martins (2010), studies involving random regression models (RRM) used so far indicate that this methodology can significantly contribute to the process of acceleration of genetic progress in beef cattle and milk, poultry, pork, fish, goats, sheep and other economically important species. This allows estimates of genetic parameters and values that are more accurate, or better and closer to the real value to allow an earlier age of the selection process.

A few studies involving random regression on fish data have been carried out, including those published by Mckay, Schaeffer and McMillan (2002) in rainbow trout, Rutten, Komen and Bovenhius (2005) with weight in Nile tilapia, Turra et al. (2012a) and Turra et al. (2012b) using random regression models in weight and fillet yield in Nile tilapia of the Chitralada strain.

This study aimed to estimate genetic parameters using random regression models in performance characteristics and morphometrics in Nile tilapia of the GIFT strain.

\section{Materials and Methods}

A set of data ceded by the PeixeGen Research Group containing information on a generation of 33 groups of full and half siblings was used. Fishes was raised at Fish Farming Experimental Station of the State University of Maringa, in Floriano city in the Paraná State. Individuals originated from matings between 180 Nile tilapia (Oreochromis niloticus) of the GIFT strain, including 60 males and 120 females. When the females showed signs of imminent spawning, the males were added. After spawning, the males were removed and the eggs were left with the females until the fingerling stage, when they were then transferred to another tank, and placed in hapas in different places in the tank. When the fingerlings reached an average of 20 grams, these animals were individually identified with a microchip (Passive Integrated Transponder Tags) implanted in the abdominal cavity, and then transported to a production system in net tanks of $4 \mathrm{~m}^{3}$ of useful area $(2.0 \times 2.0 \times 1.7 \mathrm{~m})$ at the Corvo River, in Diamante do Norte city in Paraná State.

The morphometric characteristics, body weight and daily weight gain (ADG), are the result of five individual biometrics: the first held at the time of chip sets and the other carried out at intervals of approximately 30 days during the fall and winter of 2009 (production period). The five biometrics resulted in a database of 8,590 information from 1,718 animals, totaling 1,815 animals in the relationship matrix. At the time the measurements were recorded, information was included on sex and age, beyond the individual identifying information. In addition to weight $(\mathrm{g})$, the morphometric traits evaluated were:

- Head Size $(\mathrm{cm})$ : taken from the beginning of the mouth to the opening of the operculum;

- Width (cm): measured at the insertion of the dorsal fin;

- Height (cm): the distance between the dorsal and pectoral fins; 
- Total length (cm) - TL: distance corresponding to the beginning of the mouth to the insertion of the caudal fin.
Fish measuring boards were used to measure the TL and calipers for width, height and head size.

Descriptive statistics of the database used are shown in Tables 1 and 2.

Table 1. Number of animals evaluated and the minimum, average and maximum ages of the individuals in each of the five biometrics.

\begin{tabular}{ccccc}
\hline \multirow{2}{*}{ Biometric } & \multirow{2}{*}{ No $^{\circ}$ of animals } & \multicolumn{3}{c}{ Age } \\
\cline { 3 - 5 } & & Minimum & Average & Maximum \\
\hline 1 & 1718 & 64 & 117 & 142 \\
2 & 1718 & 118 & 171 & 196 \\
3 & 1718 & 158 & 211 & 236 \\
4 & 1718 & 204 & 257 & 282 \\
5 & 1718 & 233 & 286 & 311 \\
\hline
\end{tabular}

Source: Elaboration of the authors.

Table 2. Averages and standard deviations for weight, daily weight gain (ADG), height, length (TL) and width in each of the five biometrics.

\begin{tabular}{ccccccc}
\hline \multirow{2}{*}{ Biometric } & \multicolumn{7}{c}{ Measurements } \\
\cline { 2 - 6 } & $\begin{array}{c}\text { Weight } \\
(\mathrm{g})\end{array}$ & $\begin{array}{c}\text { ADG } \\
(\mathrm{g} / \text { day })\end{array}$ & $\begin{array}{c}\text { Height } \\
(\mathrm{cm})\end{array}$ & $\begin{array}{c}\text { Head } \\
(\mathrm{cm})\end{array}$ & $\begin{array}{c}\text { TL } \\
(\mathrm{cm})\end{array}$ & $\begin{array}{c}\text { Width } \\
(\mathrm{cm})\end{array}$ \\
\hline 1 & $23.1 \pm 7.4$ & $0.2 \pm 0.1$ & $2.7 \pm 1.1$ & $2.1 \pm 0.4$ & $10.1 \pm 0.3$ & $1.1 \pm 0.4$ \\
2 & $79.2 \pm 24.3$ & $1.0 \pm 0.4$ & $4.8 \pm 1.5$ & $3.9 \pm 0.5$ & $15.1 \pm 0.3$ & $2.3 \pm 0.4$ \\
3 & $126.0 \pm 39.6$ & $1.2 \pm 0.4$ & $5.7 \pm 1.7$ & $4.1 \pm 1.1$ & $18.2 \pm 0.5$ & $2.3 \pm 0.5$ \\
4 & $190.7 \pm 60.5$ & $1.4 \pm 0.6$ & $6.5 \pm 2.1$ & $5.1 \pm 0.8$ & $21.0 \pm 0.4$ & $3.1 \pm 0.6$ \\
5 & $263.01 \pm 82.8$ & $2.5 \pm 1.0$ & $7.2 \pm 2.3$ & $5.8 \pm 0.9$ & $23.5 \pm 0.4$ & $3.2 \pm 0.6$ \\
\hline
\end{tabular}

Source: Elaboration of the authors.

The retention of eggs in the mother's mouth in species of Nile tilapia (Oreochromis Genus) characterizes the first common environmental effect, usually called the family effect. Later this effect may be the stage of creation until the identification of the individual or the rearing period until equal numbers of representatives are collected by the family. In full-sib families, the variance due to maternal effects can be absorbed by the random effect of family (RUTTEN; KOMEN; BOVENHIUS, 2005). Therefore, it is necessary to consider this effect because it includes the period from when the larvae remain with their mother until they are brought to the creation system in net tanks, which in some cases reaches four months of age.

Following the methodology of random regression models (RRM) in the context of linear mixed models, the model adopted was as follows:

$$
Y_{i j l}=F_{l}+\sum_{m=0}^{k-1} b_{m} \phi_{m}\left(a g e_{i j}^{*}\right)+\sum_{m=0}^{k-1} a_{i m} \phi_{m}\left(a g e_{i j}^{*}\right)+\sum_{m=0}^{k-1} p_{i m} \phi_{m}\left(a g e_{i j}^{*}\right)+\sum_{m=0}^{k-1} c_{i m} \phi_{m}\left(a g e_{i j}^{*}\right)+e
$$


where:

$Y_{i j l}$ the trait (weight, weight gain, height, head length or width) measured in animals $i$ at age $j$;

$F_{l}$ are the fixed effects of sex and net tank;

$b_{m}$ is the mth fixed regression coefficient;

$a_{i m}$ is the mth random regression coefficient of the additive genetic effect;

$p_{i m}$ is the mth random regression coefficient of the permanent environmental effect in the animal $i$; $c_{i m}$ is the mth random regression coefficient of the family common effect;

$e$ is the error associated with each observation

$\phi_{k}$ is the mth Legendre polynomial of $k$ order and

$a g e_{i j}^{*}$ is the jth standard age at which the trait was observed in the animal $i$.

The mth Legendre polynomial of $\mathrm{k}$ order has the following formula:

$$
\phi_{k}\left(a g e_{i j}^{*}\right)=\frac{1}{2^{k}} \sqrt{\frac{2 k+1}{2}} \sum_{m=0}^{[k / 2]}(-1)^{m}\left(\begin{array}{c}
k \\
m
\end{array}\right)\left(\begin{array}{c}
2 k-2 m \\
k
\end{array}\right)\left(a g e_{i j}^{*}\right)^{k-2 m}
$$

where:

$a g e_{i j}^{*}$ é is the jth standard age (necessary to maintain the orthogonality property between -1 and 1) in which the trait was observed in the animals i, being:

$$
a g e_{i j}^{*}=\frac{2\left(a g e_{i-} a g e_{\min }\right)}{a g e_{\max }-a g e_{\min \square}}-\mathbf{1} ;
$$

where $a g e_{i}$ is the age at time of observation, $a g e_{\min \square}$ and $a g e_{\max \square}$ are the minimum and maximum ages there are in the database, and the brackets [.] on the sum indicates that the number inside is rounded down, assuming the nearest integer value (SAKAGUTI et al., 2003).

In matrix notation, the random regression model can be represented by:

$$
Y=X \beta+Z_{1} \alpha+Z_{\mathbf{2}} p+Z_{\mathbf{3}} c+\varepsilon
$$

where:

$Y$ is the vector of observed values for weight, weight gain, height, head length or width;

$X$ is the matrix of fixed effects of sex and net tank (four levels);

$\alpha$ is the vector of random regression coefficients of the genetic effect;

$p$ is the vector of random regression coefficients for permanent environmental effect of the individual; $c$ vector of random regression coefficients of the family common effect (105 levels)/

$Z_{1}, \quad Z_{2}$ and $Z_{3}$ are the incidence matrices of the genetic effect, permanent environmental and family, respectively, and

$\varepsilon$ is the vector of random errors.

The following assumptions were made: $E(Y)=X \beta, \quad E(a)=E(p)=E(\varepsilon)=\mathbf{0}$, $\operatorname{Var}(a)=A \otimes K_{a}, \quad \operatorname{Var}(p)=I \otimes K_{p}$, $\operatorname{Var}(c)=I \otimes K_{c}$ and $\operatorname{Var}(e)=R$, with $K_{a}$ the matrix of (co) variance between random regression coefficients of permanent environmental effect, $A$ the relationship matrix, $K_{p}$ the matrix of (co) variance between random regression coefficients of permanent environmental effect, $K_{c}$ the matrix of (co) variance between random regression coefficients of the family common effect, $I$ an identity matrix and e $($ the Kronecker product.

The random effects of additive genetic, permanent environmental and family have different covariance structures. The estimation of covariance between random regression coefficients produces estimates of covariance functions. The covariance functions for the genetic effect were calculated by:

$$
f\left(a g e_{l}^{*} a g e_{m}^{*}\right)=\sum_{l=0}^{k-1} \sum_{m=0}^{k-1} \phi_{l}\left(a g e_{l}^{*}\right) \phi_{m}\left(a g e_{m}^{*}\right) K_{a_{i j}}
$$


where:

$f\left(a g e_{l}^{*} a g e_{m}^{*}\right)$ is the covariance function to weight or morphometric measurement between ages 1 and $\mathrm{m}$;

$K$ é is the fit order of the polynomial;

$\phi_{l}, \phi_{m}$ are the $k$ Legendre polynomials for ages $l$ and $m$, respectively;

$K_{a_{i j}}$ are the elements of matrix of (co) variances between the coefficients of additive genetic effect of the function of (co) variance, estimated by random regression;

$a g e_{l}^{*} a g e_{m}^{*}$ are the lth and mth standardized age for the interval at which the polynomial was defined.

In matrix notation, the covariance function $(\mathrm{CF})$ can be described as

$$
\widehat{G}=\Phi K_{a} \Phi^{\prime}
$$

where:

$\widehat{G}$ é a the covariance matrix of the regression coefficients of random additive genetic effect;

$\Phi$ is matrix with orthogonal polynomials and

$K_{a}$ is the covariance matrix of the coefficients of additive genetic of $\mathrm{CF}$, estimated by random regression.

Estimates of (co) variances were obtained using the WOMBAT software (MEYER, 2007) using the method of restricted maximum likelihood (REML). Models with orders of 2, 3 and 4 of Legendre polynomials for the additive genetic effect, and orders of 2 and 3 for age, permanent environmental and family effects were tested. In addition, residual variance homogeneous and heterogeneous models for age classes, were tested as described in Table 3. Classes were formed so that each class had the same size in number of days. To define the most appropriate model, two criteria were used:

$1^{\circ}$ - presence of at least one close to zero in absolute value (NOBRE et al., 2003) or an eigenvalue smaller than $1.2 \%$ of the relative values of the covariance matrix random regression coefficients, for each of the random effects;

$2^{\circ}$ - models that met the 1 st requirement were compared by the maximum likelihood test statistic (LR). This test increasing order or increasing number of parameters is considered expressive when their inclusion leads to a significant increase in maximum likelihood log. (SARMENTO et al., 2006). The LR statistic is:

$$
L R_{i j}=2 \log L_{i}-2 \log L_{j},
$$

where $i$ and $j$ models are to be compared. The estimated LR was compared to the chi-square value (tabulated $\chi^{\mathbf{2}}$ ), with the degree of freedom being the difference between the number of model parameters and compared to the significance level of 0.01 .

Table 3. Number of class residual variance used in the analysis and their respective age ranges.

\begin{tabular}{cc}
\hline $\mathrm{N}^{\circ}$ of class $\sigma_{\boldsymbol{\theta}}^{\mathbf{2}}$ & Age (days) \\
\hline 1 & $60-330$ \\
\hline 3 & $60-150$ \\
& $151-240$ \\
$241-330$ \\
\hline & $60-105$ \\
6 & $106-151$ \\
& $152-197$ \\
& $198-243$ \\
& $244-289$ \\
& $290-330$ \\
\hline & $60-90$ \\
& $91-120$ \\
& $121-150$ \\
9 & $151-180$ \\
& $181-210$ \\
& $211-240$ \\
& $241-270$ \\
& $271-300$ \\
& $301-330$
\end{tabular}

Source: Elaboration of the authors. 


\section{Results and Discussion}

The means of morphometric characteristics, body weight and weight gain shown in Table 2 are within those recommended for the cultivation of Nile tilapia, allowing good performance of fish (LUNDSTEDT; LEONHARDT; DIAS, 1997; BOSCOLO et al., 2001; LEONHARDT et al., 2006).

Considering the traits of weight, total length and width, suitable models of heterogeneous residual variance were considered with nine classes for weight and length, with three classes of residual variance for the width. For other traits, models considering homogeneous residual variance presented the best fit. Turra et al. (2012a) also found a better fit for the weight in the tilapia Chitralada strain by models considering heterogeneous residual variance with 10 classes in 14-day intervals.

In all the studied traits, the effects of permanent environment and family had eigenvalues equal to zero in the analysis of third order, denoting no need to increase the order (Table 4).

For genetic effects, considering only the GPD and width, the results show that the fit with Legendre polynomials of order 3 was enough, because there was at least one eigenvalue equal to zero. For the traits of weight, length, height and head size, it was necessary to increase the order, with that for weight and length increased to the 4th order. If reducing the eigenvalues of the covariance matrix between the random coefficients did not lead to a significant increase in LogL, a third-order model was chosen. An increase to a 4th-order Legendre polynomial for height and head size led to a significant increase in LogL suggesting this was the most appropriate setting order for the genetic effect for these traits (Table 4).

An intercept (b0) with high genetic variance means that there is great genetic variability for the trait in the intermediary age, in that case 188 days (the intercept of a Legendre polynomial is in the middle of the range of -1 to +1 , and therefore this is the age when standardization returns the value to zero, being the midpoint between the maximum and minimum age present in the data set). Furthermore, when the eigenvalue relative (AV\%) is high, selection based on this coefficient would lead to more rapid changes than that based on another coefficient, because it represents a large part of the genetic variation. As for all the traits, the intercept was responsible for over $78 \%$ of the total genetic variance (AV\% - Table 4); changes based on modifications in this coefficient for all traits could lead to more rapid changes than those based on other coefficients. 


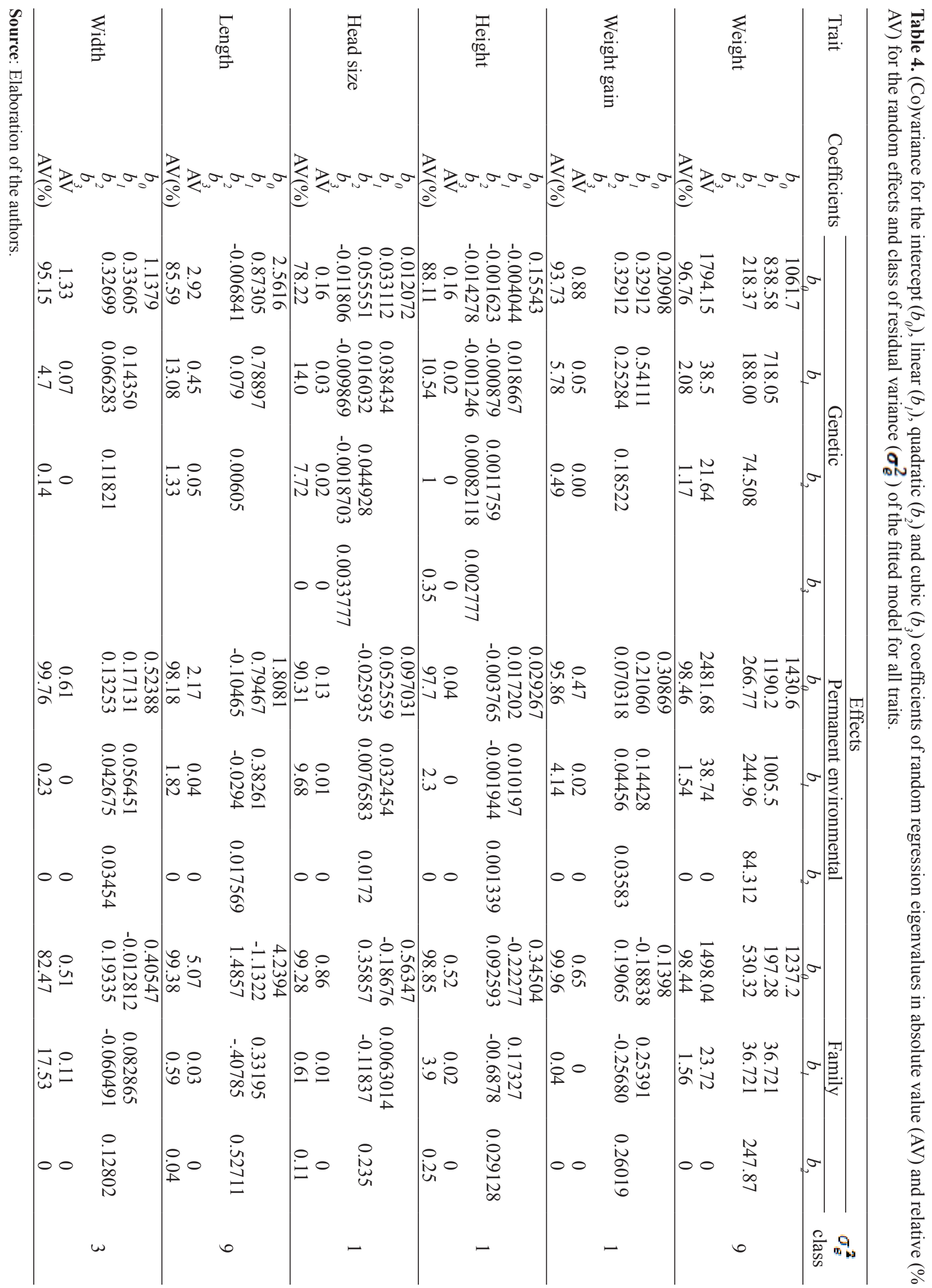


If linear and quadratic coefficients are positively related, and therefore the covariance between them is positive, animals with a higher linear coefficient show greater inclination in their growth trajectory. In this study, the relationship between b0 and b1 was positive for most traits, except for the head size, indicating that animals with larger head sizes at 188 days have lower acceleration in the growth of head size. Figures 1, 2 and 3 show the behavior of additive genetic variance, permanent environmental and family over the course of age of the evaluated traits. Overall, the phenotypic variance undergoes an initial decrease to 120-150 days of age, then stabilizes and increases again at around 220 days. Possibly the greatest magnitude of the variance of permanent environmental effect on some characteristics reflects the variance overestimation of this effect for larger than 220 days of age, while also promoting an increase in the estimates of phenotypic variance. For weight (Figure 1), the same behavior was observed by Rutten, Komen and Bovenhius (2005) and Turra et al. (20012a). The behavior of the phenotypic variance for height did not follow this pattern because there was greater initial variation, which stabilized at 120 days. Although length and width followed this pattern (Figure 3) (initial decline and increase at the end), there was an abrupt change in the genetic and phenotypic variation between 150 and 180 and between 150 and 250 days, respectively. Possibly, this increase in phenotypic variance is caused by entry into sexual maturity, which occurs between the 4th and 6th months of life. The residual variance (Figures 1, 2 and 3) was smaller than the other variances in most of the evaluation period except for the residual variance for the length (Figure 3), which was initially greater than the genetic, environmental and family permanent. This lower residual variance is possibly due to adequate experimental control (TURRA et al., 2012a).

The behavior of the variance for permanent environment, additive genetic and family is best viewed when expressed relative to the phenotypic variation. Figures 4, 5 and 6 show the ratios of the genetic variance $\left(h^{2}\right)$, permanent environment $\left(\mathrm{pe}^{2}\right)$ and family $\left(\mathrm{c}^{2}\right)$ in relation to the phenotypic variation.

It was observed that the effect of family variance decays throughout the life of the animal for all traits, as expected, since the influence of the family effect exercises a major importance during the early life of the animal. Such behavior is because this effect includes maternal effects, the effect of permanence of eggs in the female's mouth and the effect that comes from being created to identify the individual. For weight (Figure 4), this behavior differs from the one reported by Rutten, Komen and Bovenhius (2005), who estimated, using four strains of tilapia, that the change due to family effect remains low throughout the study period. The in vitro analyses of these authors may have reduced the variation of effect of family due to the no permanence of fish with the parent during the incubation period. Based on the results of Turra et al. (2012a), working with the Chitralada strain, the $\mathrm{c}^{2}$ ranged from 0.7 to 0.4 , thus presenting a similar behavior obtained in the present study. 
Figure 1. Phenotypic $\left(\sigma_{p}^{2}\right)$, additive genetic $\left(\sigma_{a}^{2}\right)$, permanent environmental $\left(\sigma_{p e}^{2}\right)$, family $\left(\sigma_{c}^{2}\right)$ and residual variances $\left(\sigma_{e}^{2}\right)$ for weight (left) and weight gain (right) as a function of age, estimated by random regression models.
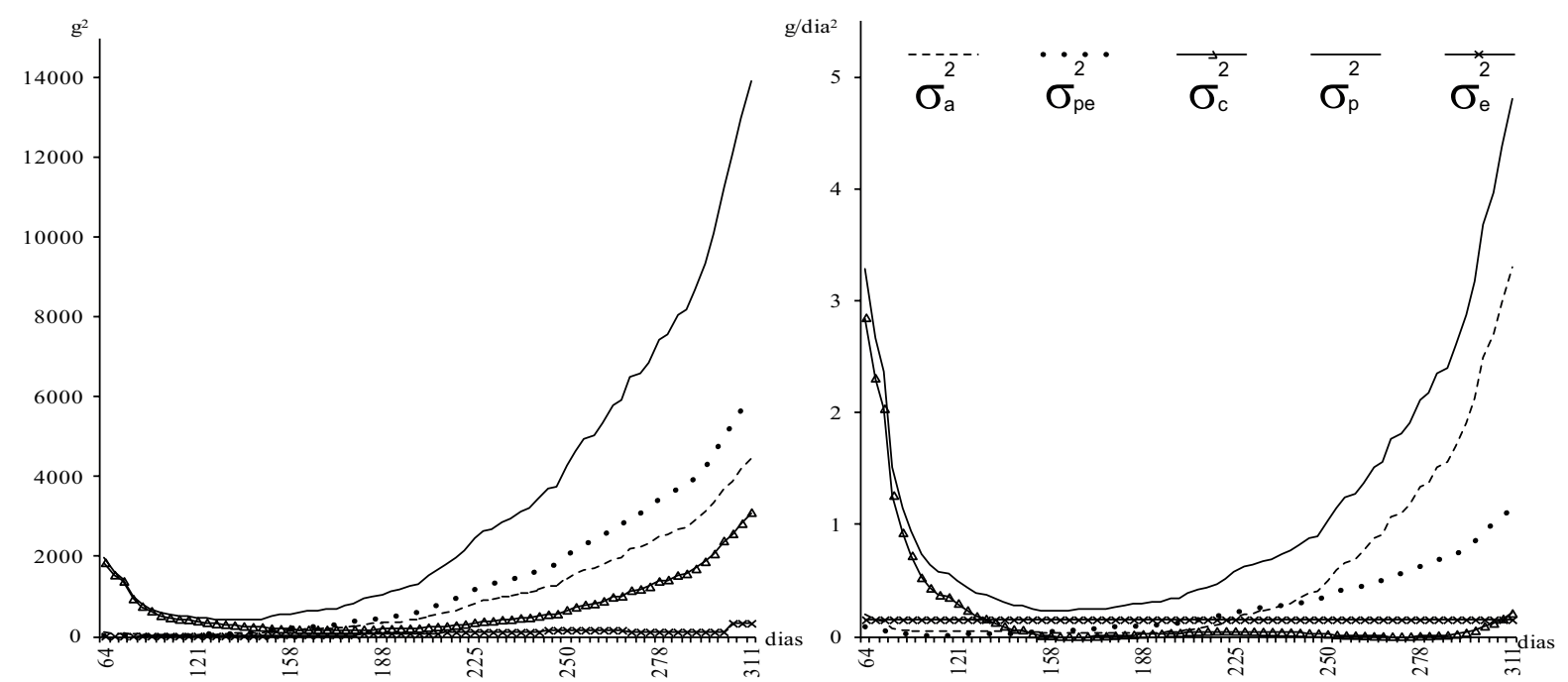

Source: Elaboration of the authors.

Figure 2. Phenotypic $\left(\sigma_{p}^{2}\right)$, additive genetic $\left(\sigma_{a}^{2}\right)$, permanent environmental $\left(\sigma_{p e}^{2}\right)$, family $\left(\sigma_{c}^{2}\right)$ and residual variances $\left(\boldsymbol{\sigma}_{\boldsymbol{e}}^{2}\right)$ for height (left) and head size (right) as a function of age, estimated by random regression models.
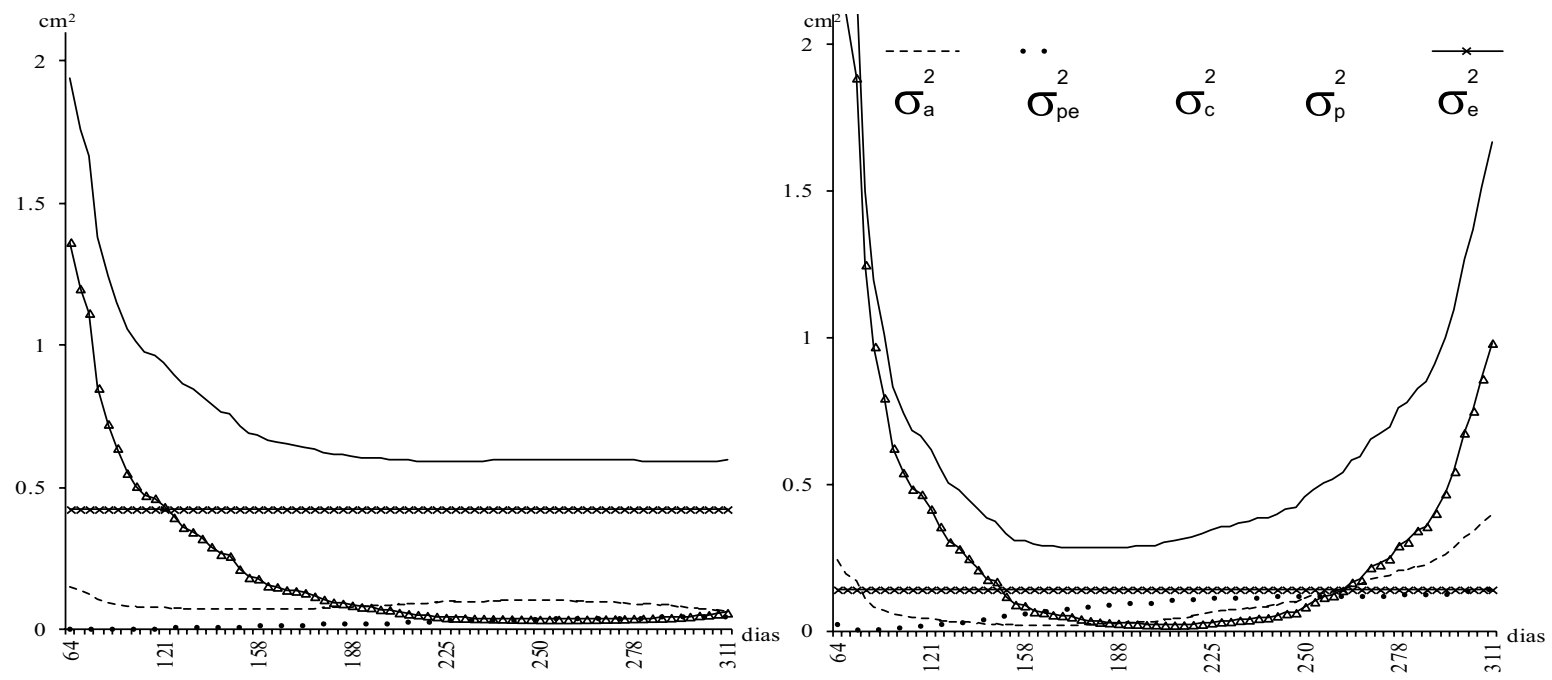

Source: Elaboration of the authors.

Head (Figure 5), length and width (Figure 6) showed increases in $\mathrm{c} 2$ at the end of the study period. This may be due to the order of adjustment because there is no biological justification for increasing the contribution variance of the family effect during this period of life of the individual. In addition, according to Rutten, Komen and Bovenhius (2005) and Sakaguti et al. (2003), the polynomials are known to change the direction of the estimates in the extremities of the data. 
Figure 3. Phenotypic $\left(\boldsymbol{\sigma}_{p}^{2}\right)$, additive genetic $\left(\boldsymbol{\sigma}_{a}^{2}\right)$, permanent environmental $\left(\boldsymbol{\sigma}_{p e}^{2}\right)$, family $\left(\boldsymbol{\sigma}_{c}^{2}\right)$ and residual variances $\left(\sigma_{e}^{2}\right)$ for length (left) and width (right) as a function of age, estimated by random regression models.

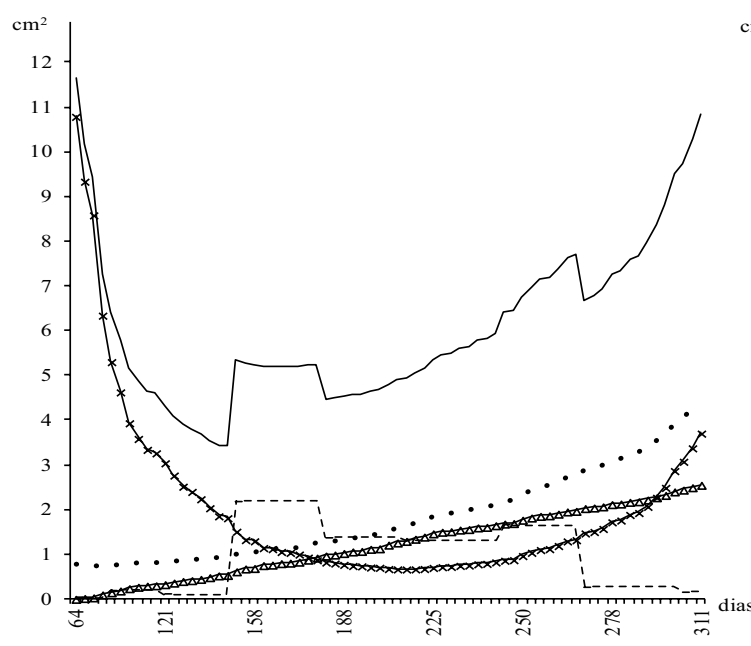

Source: Elaboration of the authors.

Overall, the proportion of the permanent environmental variance (Figures 4, 5 and 6) increased to 170 days of age of the animal, the evaluated traits and decreased slightly at the end of the study period. This increased importance of the permanent environmental effect over the study period is due to the decrease in the importance of the effect of family. Rutten, Komen and Bovenhius (2005) found the same behavior for the importance of the proportion of permanent environmental variance relative to phenotypic variance in weight in tilapia. According to these authors, efforts to reduce the environmental effects are needed early, when selection decisions are made based on the performance of the animals, since the effects that are not genetic and / or from a common environment may impact over a long period in the life of the animal.

Figure 4. Heritability $\left(\mathrm{h}^{2}\right)$, proportion of permanent environmental variance $\left(\mathrm{pe}^{2}\right)$ and proportion of family $\left(\mathrm{c}^{2}\right)$ in relation to phenotypic variation for weight (left) and weight gain (right) as a function of age, estimated by random regression models.
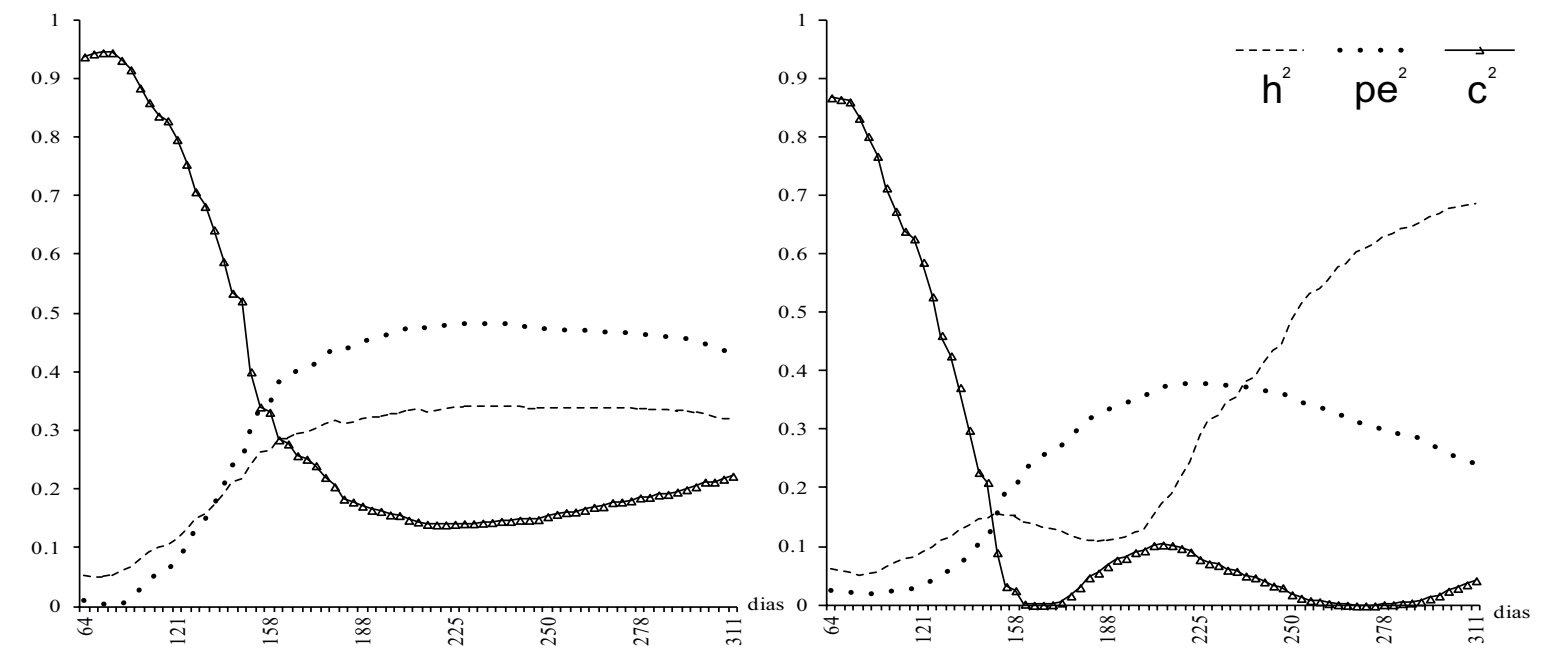

Source: Elaboration of the authors. 
Figure 5. Heritability $\left(\mathrm{h}^{2}\right)$, proportion of permanent environmental variance $\left(\mathrm{pe}^{2}\right)$ and proportion of family $\left(\mathrm{c}^{2}\right)$ in relation to phenotypic variation for height (left) and head size (right) as a function of age, estimated by random regression models.
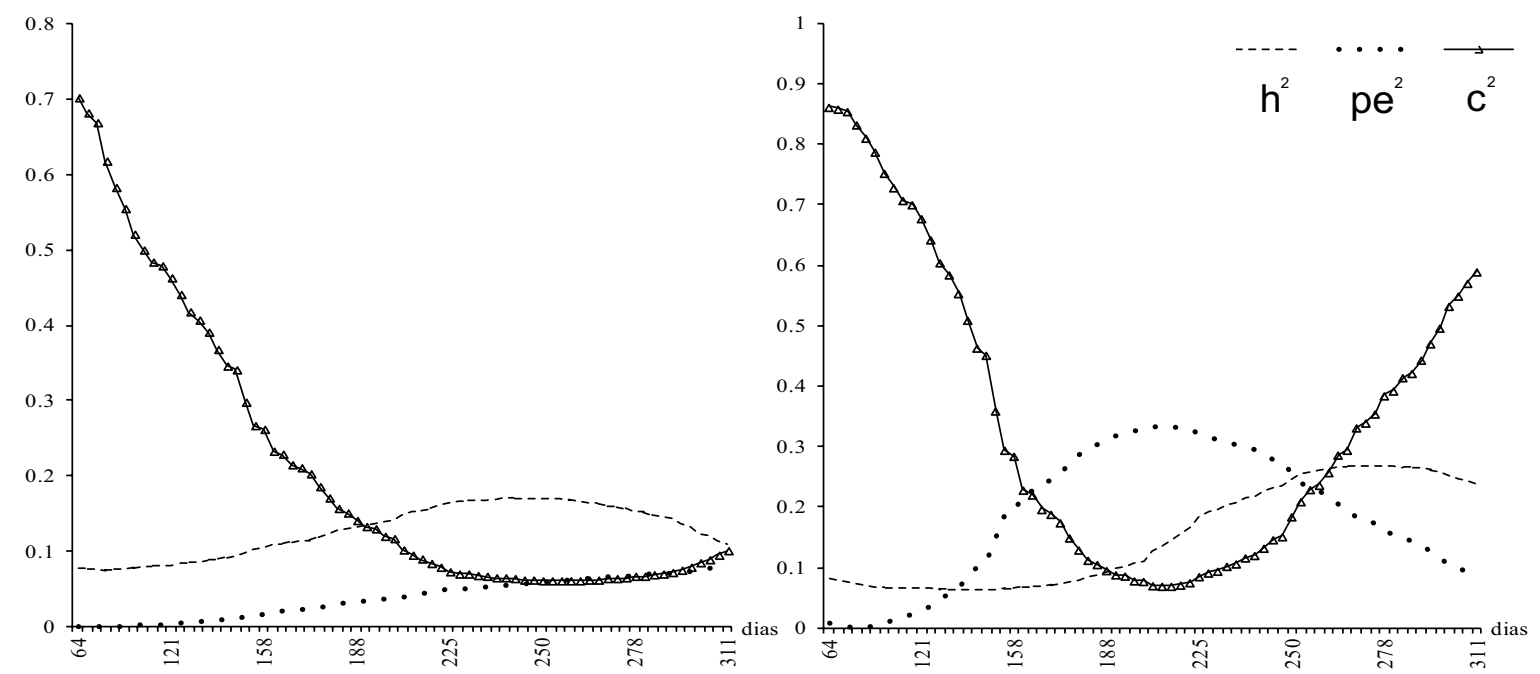

Source: Elaboration of the authors.

Figure 6. Heritability $\left(\mathrm{h}^{2}\right)$, proportion of permanent environmental variance $\left(\mathrm{pe}^{2}\right)$ and proportion of family $\left(\mathrm{c}^{2}\right)$ in relation to phenotypic variation for length (left) and width (right) as a function of age, estimated by random regression models.
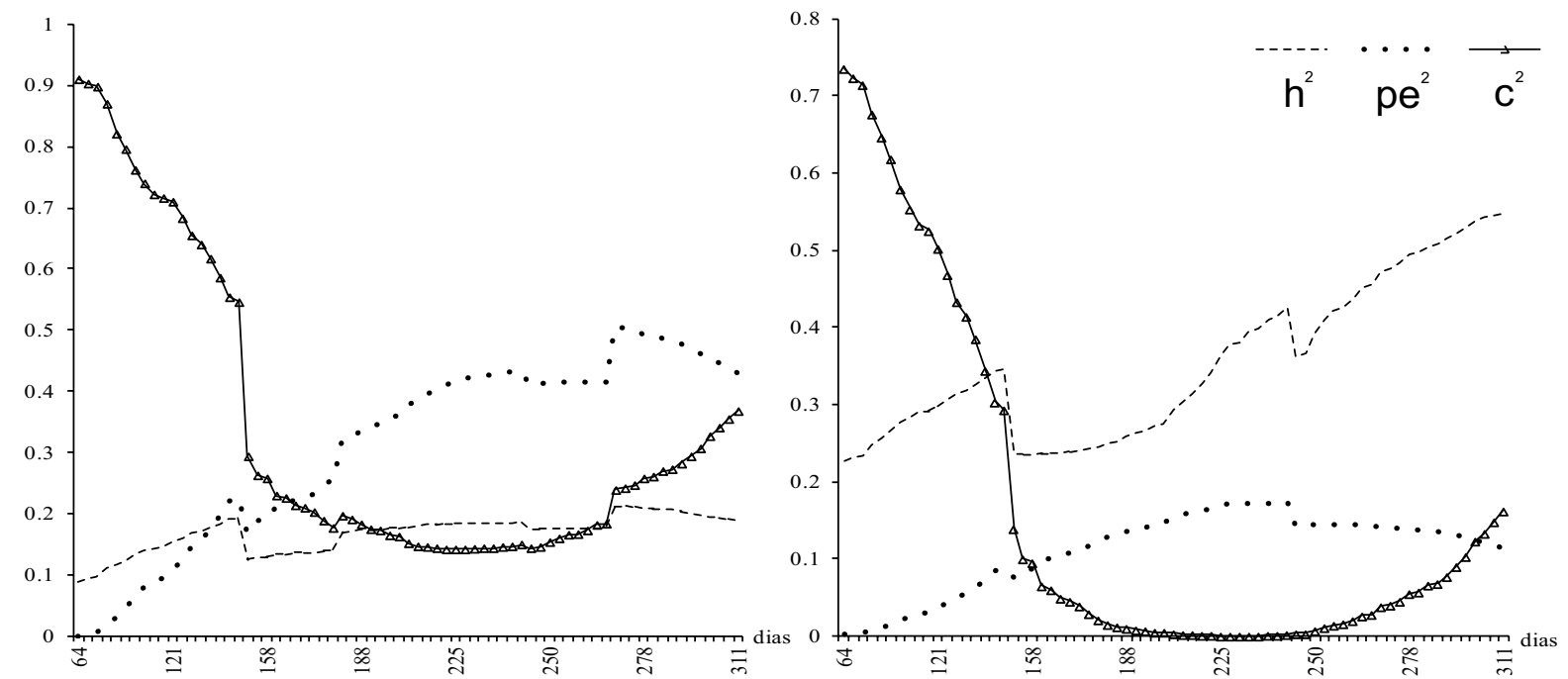

Source: Elaboration of the authors.

Heritability showed very small initial values for most of the traits $(\mathrm{h} 2<0.10)$. For weight (Figure 4), the $\mathrm{h} 2$ increased to 0.30 at 170 days and then grew very little, until reaching 0.34 at 240 days and remained at that level until the end of the study period. These results indicate that the weight selection should be based on ages of more than 170 days for the response to selection to become satisfactory. Similar results were reported by Rutten, Komen and Bovenhius (2005), where h2 increased to 0.20 at 140 days, reaching its maximum value at 250 days (0.24) and decreasing until the end of the 
study period (0.15); however, the results of Turra et al. (2012a), showed that the h2 reached 0.52 at the end of the study period. The highest values of heritability found in the higher ages in the present study are possibly due to a decreased effect of family. Turra et al. (2012a) recommended that groups of siblings and half siblings should be separated as soon as possible so that genetic differences manifest early. Among the traits evaluated, the highest $\mathrm{h} 2$ was found for weight gain (Figure 4), which increased to 150 days $(0.15)$ and then presented a slight decrease (0.11) and increased linearly until the end of the period evaluated, reaching 0.69 to 311 days of age.

For height (Figure 5), the h2 was low throughout the period evaluated, reaching 0.2 to 254 days. For the head, h2 grew slightly to 190 days (0.09) and reached 0.27 at 270 days, decreasing slightly until the end of the study period.

The phenotypic and genetic variances for length increased by around 150 to 180 days; however, the genetic variance did not increase in the same proportion as the phenotypic. Therefore, the $\mathrm{h} 2$ dropped in this period and then increased to reach 0.21 at 270 days (Figure 6). The results of this study showed a greater influence of permanent environmental effect and a family genetic effect for a length of 150 to 180 days.

Among the traits evaluated, the width showed the highest initial value of $\mathrm{h} 2$ (0.24) increases until 140 days (0.34), after which it declined returning to almost the same values at 240 days. After this it decreased again, and then increased until it reached its maximum value (0.54) at 311 days. This behavior is due to the increase in phenotypic variance (Figure 6).

According to these results, the traits that would have better responses to selection were weight, weight gain and width, which showed h2 values of greater than 0.30 . Heritability is usually used to infer about genetic gain; however, it is a predictor of breeding value and therefore if the selection is based on the phenotypic value of individuals (phenotypic selection), it is important because it expresses the reliability of the phenotypic value as an indication of genetic value. But if the selection is based directly on the genetic value of the trait, the genetic variability itself is what determines whether there is a possibility of genetic gain and not the ratio to the total phenotypic variance. The presence of variance indicates that genetic gain can be achieved (PONZONI et al., 2005). Therefore, even if the heritability is low, as in most of the traits evaluated in this study, and the genetic variability that increases at the end of the period evaluated for most of the traits can be an indication that genetic gains are possible.

Figures 7,8 and 9 show the genetic correlations between different ages. It is observed that the correlation increases between more similar ages, i.e., the most similar ages are more correlated. Overall, genetic correlations for 300 days and other ages are greater when close to the 200 days of age, indicating selections at ages of more than 200 days do not lead to genetic gains correlated in a trait at 300 days, except for width, where high correlations were obtained between the final and initial ages.

For weight (Figure 7), ages above 160 days showed higher genetic correlations with older ages, suggesting that if the purpose of selection is weight at the end of the growing season, the selection should be based on ages greater than 160 days. Similar results were obtained by Turra et al. (2012a), however, as the study period was lower (106-245) than that used in the present study (64-311), they found higher correlations. Rutten, Komen and Bovenhius (2005), used a similar period as the present study (100-325), and reported a genetic correlation with 325 day, which was greater than 0.8 at 175 days.

The commercial weight of tilapia is between $500 \mathrm{~g}$ (PAIVA et al., 2008) and $600 \mathrm{~g}$ (RUTTEN; KOMEN; BOVENHIUS, 2005), although there is a market for larger animals (600-850 g) (Nogueira; Rodrigues, 2007). If individuals are able to reproduce around the 4th and 5th month of life (120 and 150 days of 
age) (OLIVEIRA; SANTOS; PEREIRA, 2007), parents of the next generation could be chosen when they reach sexual maturity decreasing the interval between generations and costs with later biometrics. In temperate regions, such as southern Brazil, where the animals were raised, the early selection would not diminish the interval between generations, since cold temperatures limit the reproduction of tilapia. In these places, early selection would be useful only to reduce expenses with later biometrics.

Figure 7. Genetic correlation between the different ages for weight (left) and weight gain (right) estimated by random regression models.
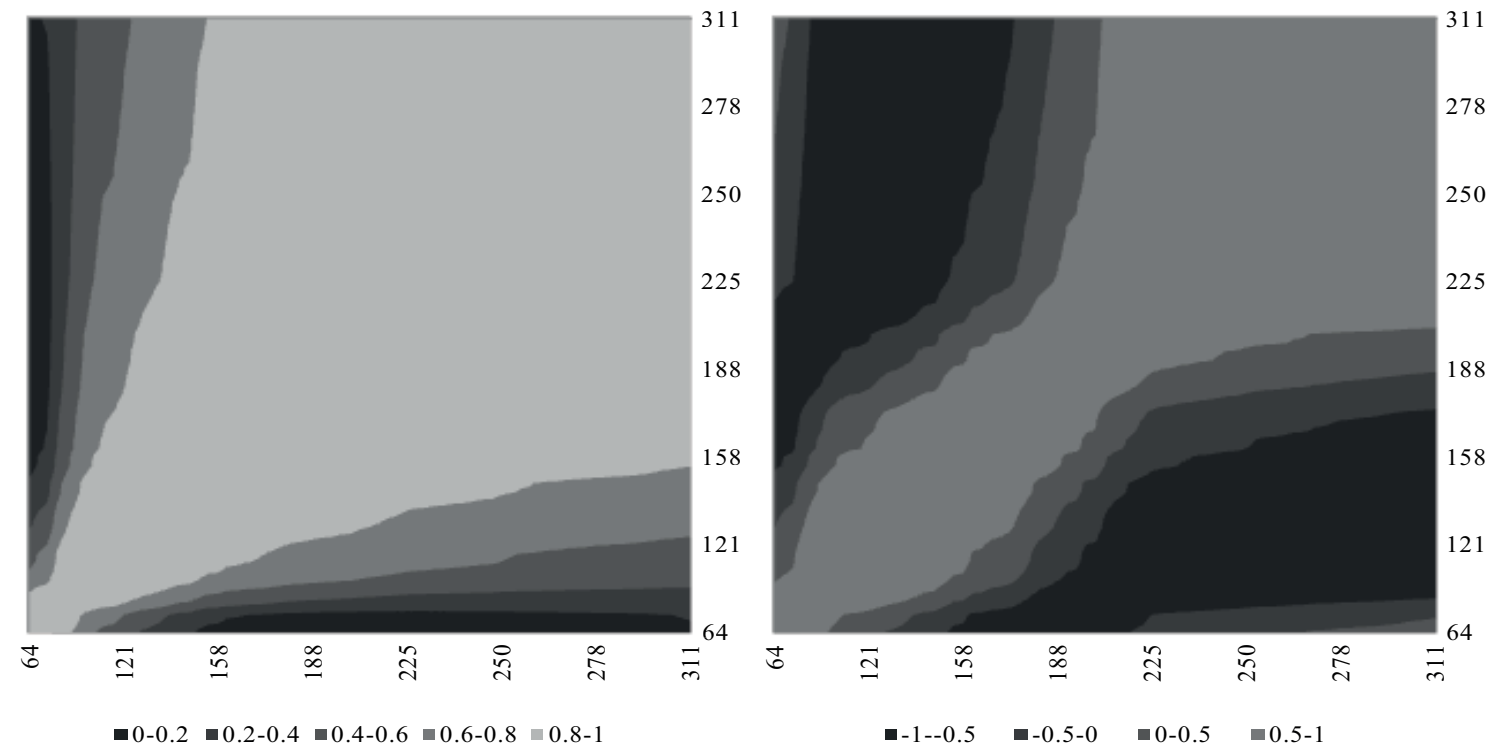

Source: Elaboration of the authors.

Figure 8. Genetic correlation between the different ages for height (left) and head size (right) estimated by random regression models.
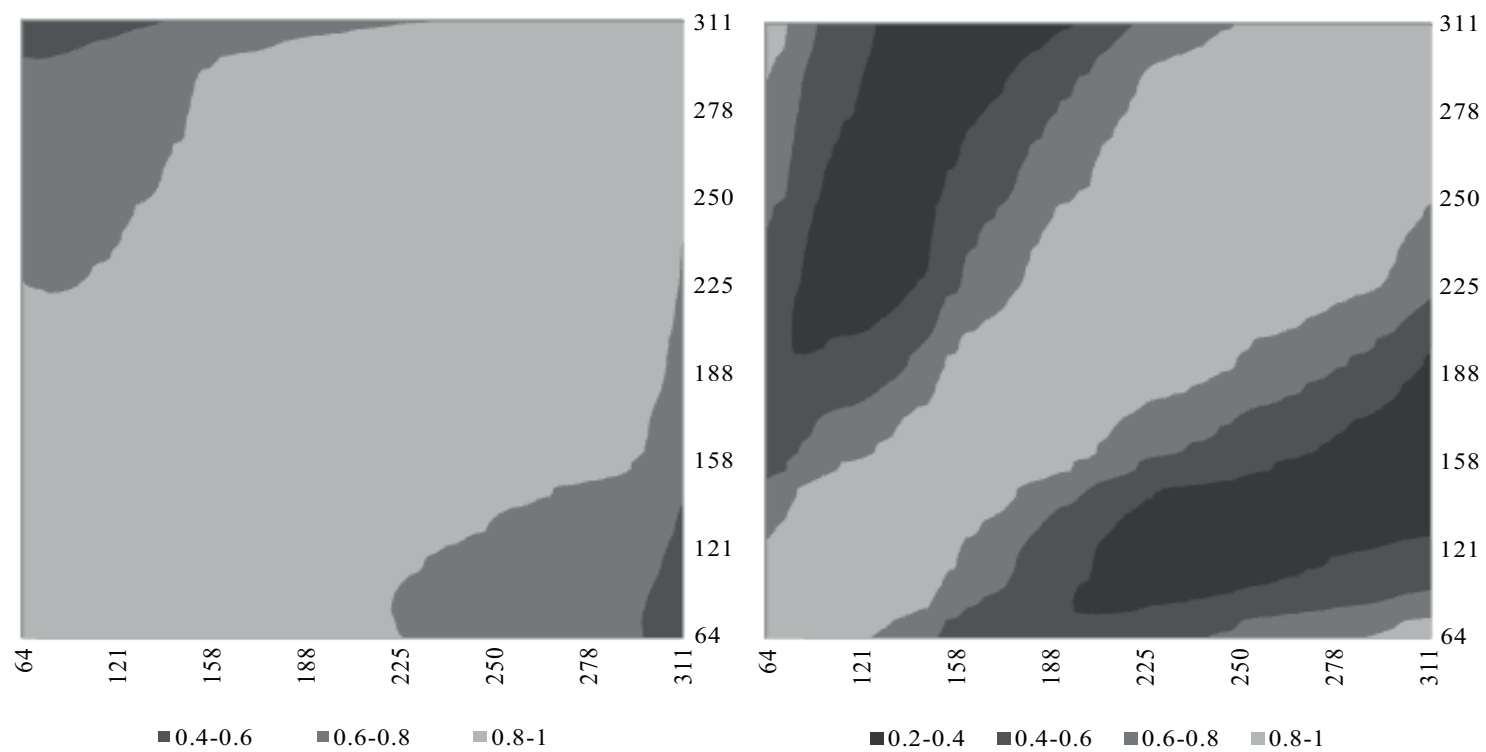

Source: Elaboration of the authors. 
Figure 9. Genetic correlation between the different ages for length (left) and width (right) estimated by random regression models.

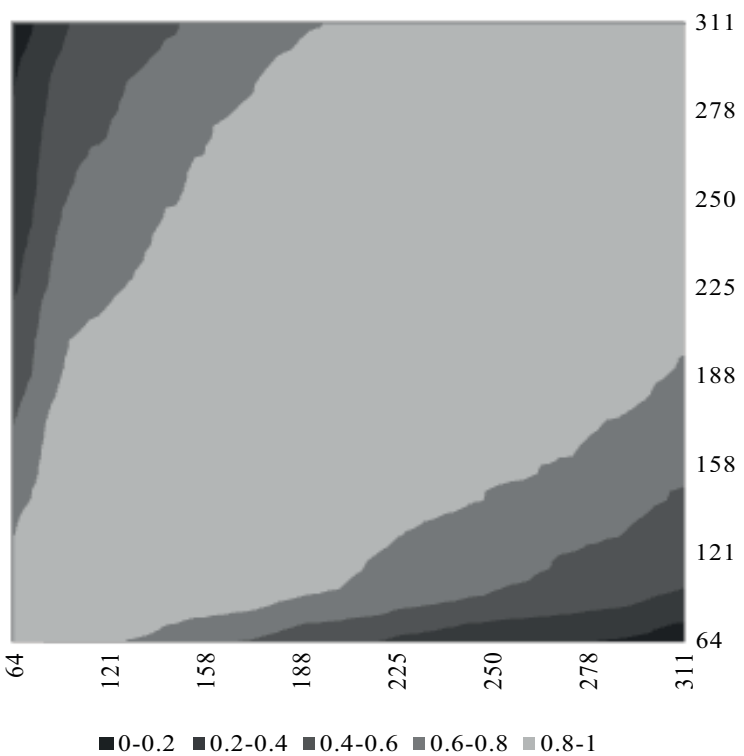

Source: Elaboration of the authors.

As the heritability for weight is higher after 160 days of age and the correlation between weight at 300 days and weight at 160 days is greater than 0.80 , it is concluded that the weight at ages of more than 160 days can be a selection criterion when the purpose of the selection is weight at 300 days.

For weight gain (Figure 7), positive genetic correlations were found between 300 days and ages of more than 200 days; however, as the $\mathrm{h} 2$ is higher at the end of the study period, selection at lower ages are not as advantageous as at 300 days.

For height (Figure 8) and length (Figure 9), genetic correlations to 300 days of age become more than 0.80 after 190-200 days of age. Thus, the selection of ages greater than 200 days would lead to genetic gains similar to those obtained if the selection was based on the trait at 300 days; however, there would be discrete gains, since a low magnitude of h2 was measured throughout the period.

Genetic correlations for head size at 300 days are greater than 0.8 for ages of more than 250 days (Figure 8). If the intention in the selection process is

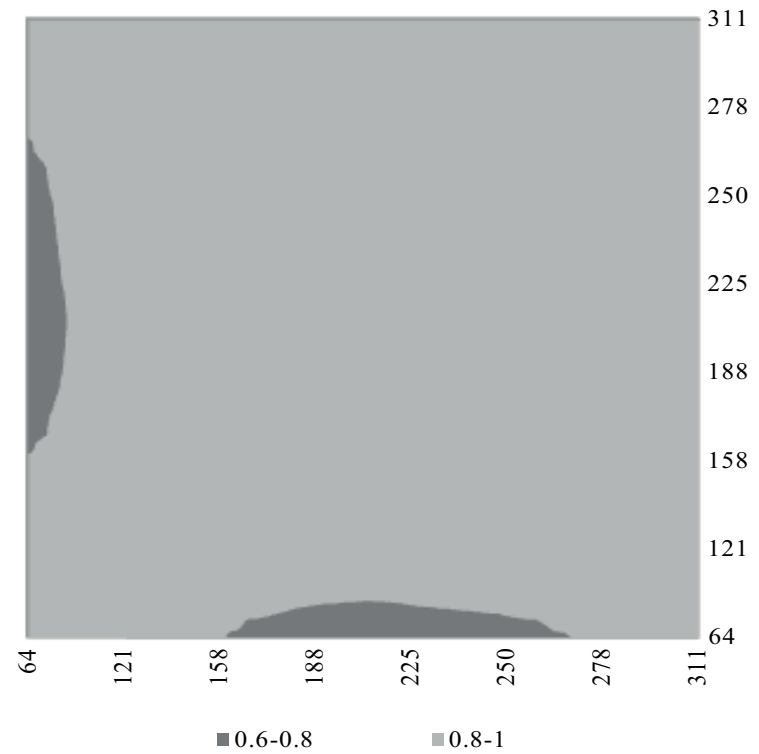

to decrease the size of the head and since $\mathrm{h} 2$ is the highest at 270 days, a selection based on this age would lead to genetic gain in head size at 300 days.

For the width (Figure 9), the genetic correlations were high for all ages, except for those aged between 160 and 260 days and between 60 and 70 days. As the h2 for the width was moderate to high throughout the study period, selection based on any age would also lead to a genetic gain in width at 300 days.

\section{Conclusions}

Heritability estimates were low to moderate and increased over the study period, suggesting that selection at older ages provides larger genetic gains. The highest heritabilities were obtained for weight gain and width, indicating that higher gains would be obtained if these traits were used as selection criteria. High correlations for more than 200 days denote the possibility of using a slightly lower than usual age (300 days) as a selection criterion without decreasing the genetic gain. 


\section{References}

BOSCOLO, W. R.; HAYASHI, C.; SOARES, C. M.; FURUYA, W. M.; NAGAE, M. Y. Desempenho e características de carcaça de machos revertidos de tilápia do Nilo, Oreochromis niloticus, linhagens tailandesa e comum, nas fases inicial e de crescimento. Revista Brasileira de Zootecnia, Viçosa, v. 30, n. 5, p. 1391-1396, set./out. 2001.

LEONHARDT, J. H.; CAETANO FILHO, M.; FROSSARD, H.; MORENO, A. M. Características morfométricas, rendimento e composição do filé de tilápia do Nilo, Oreochromis niloticus, da linhagem tailandesa, local e do cruzamento de ambas. Semina: Ciências Agrárias, v. 27, n. 1, p. 125-132, jan./mar. 2006.

LOURENÇO, D. A. L.; MAIA, F. M. C.; MARTINS, E. N. Regressão aleatória: ferramenta quantitativa para uma melhor utilização da genética animal. In: MARTIN, T. N.; WACLAWOVSKY, A. J.; KUSS, F.; MENDES, A. S.; BRUN, E. J. Sistemas de produção agropecuária. Dois Vizinhos: UTFPR, 2010. p. 177-201.

LUNDSTEDT, L. M.; LEONHARDT, J. H.; DIAS, A. L. Alterações morfométricas induzidas pela reversão sexual em tilápia do Nilo, Oreochromis niloticus (Linnaeus, 1757). Revista Unimar, Maringá, v. 19, n. 2, p. 461-472, 1997.

MCKAY, L. R.; SCHAEFFER, L. R.; MCMILLAN, I. Analysis of growth curves in rainbow trout using random regression. In: WORLD CONGRESS ON GENETICS APPLIED TO LIVESTOCK PRODUCTION, 7., 2002, Castanet-Tolosan. Proceedings... Castanet-Tolosan: Organizing committee WCGALP, 2002. p. 6-11.

MEYER, K. WOMBAT-A tool for mixed model analysis in quantitative genetics by restricted maximum likelihood (REML). Journal of Zhejiang University- Science B, Hangzhou, v. 8, n. 11, p. 815-821, 2007.

NOBRE, P. R. C.; MISZTAL, I.; TSURUTA, S.; BERTRAND, J. K.; SILVA, L. O. C.; LOPES, P. S. Analyses of growth curves of Nellore cattle by multipletrait and random regression models. Journal of Animal Science, Champaign, v. 81, n. 4, p. 918-926, abr. 2003.

NOGUEIRA, A. C.; RODRIGUES, T. Criação de tilápias em tanques-rede. Salvador: Sebrae, 2007. 24 p.

OLIVEIRA, E. G.; SANTOS, F. J. S.; PEREIRA, A. M. L. Produção de tilápia: mercados, espécie, biologia e recria. Teresina: Embrapa Meio-Norte/MAPA, 2007. 12 p.

PAIVA, P.; PINTO, C. S. R. M.; VERANI, J. R.; SILVA, A. L. Produção da tilápia tailandesa Oreochromis niloticus, estocada em diferentes densidades em tanques-rede de pequeno volume instalados em viveiros de piscicultura povoados ou não com a mesma espécie. Boletim do Instituto de Pesca, São Paulo, v. 34, n. 1, p. 79-88, 2008.

PONZONI, R. W.; HAMZAH, A.; TAN, S.;
KAMARUZZAMAN, N. Genetic parameters and response to selection for live weight in the GIFT strain of Nile tilapia (Oreochromis niloticus). Aquaculture, Amsterdam, v. 247, n. 1-4, p. 203-210, jun. 2005.

RIBEIRO, R. P. Espécies exóticas. In: MOREIRA, H. L. M.; VARGAS, L.; RIBEIRO, R. P.; ZIMMERMANN, S. Fundamentos da moderna aquicultura. Canoas: ULBRA, 2001, p. 91-121.

RUTTEN, M. J. M.; KOMEN, H.; BOVENHUIS, H. Longitudinal genetic analysis of Nile tilapia (Oreochromis niloticus L.) body weight using a random regression model. Aquaculture, Amsterdam, v. 246, n. 1-4, p. 101113, maio 2005

SAKAGUTI, E. S.; SILVA, M. A.; QUAAS, R. L.; MARTINS, E. N.; LOPES, P. S.; SILVA, L. O.C. Avaliação do crescimento de bovinos jovens da raça tabapuã, por meio de análises de funções de covariâncias. Revista Brasileira de Zootecnia, Viçosa, v. 32, n. 4, p. 864-874, jul./ago. 2003.

SARMENTO, J. L. R.; TORRES, R. A.; SOUSA, W. H.; PEREIRA, C. S.; LOPES, P. S.; BREDA, F. C. Estimação de parâmetros genéticos para características de crescimento de ovinos Santa Inês utilizando modelos uni e multicaracterísticas. Arquivo Brasileiro de Medicina Veterinária e Zootecnia, Belo Horizonte, v. 58, n. 4, p. 581-589, jul. 2006.

SILVA, F. V.; ALMEIDA, N. L. S.; VIEIRA, J. S.; TESSITORE, A. J. A.; OLIVEIRA, L. L. S.; SARAIVA, E. P. Características morfométricas, rendimentos de carcaça, filé, vísceras e resíduos em tilápias do nilo em diferentes faixas de peso. Revista Brasileira de Zootecnia, Viçosa, v. 38, n. 8, p. 1407-1412, ago. 2009.

SOUZA, M. L. R. Industrialização, comercialização, e perspectivas. In: MOREIRA, H. L. M.; VARGAS, L.; RIBEIRO, R. P.; ZIMMERMANN, S. Fundamentos da moderna aquicultura. Canoas: ULBRA, 2001. p. 149-181.

TURRA, E. M.; OLIVEIRA, D. A. A.; VALENTE, B. D.; TEIXEIRA, E. A.; PRADO, S. A.; MELO, D. C.; FERNANDES, A. F. A.; ALVARENGA, E. R.; SILVA, M. A. Estimation of genetic parameters for body weights of Nile tilapia Oreochromis niloticus using random regression models. Aquaculture, Amsterdam, v. 354-355, p. 31-37, jul. 2012a.

TURRA, E. M.; OLIVEIRA, D. A. A.; VALENTE, B. D.; TEIXEIRA, E. A.; PRADO, S. A.; ALVARENGA, E. R.; MELO, D. C.; FELIPE, V. P. S.; FERNANDES, A. F. A.; SILVA, M. Longitudinal genetic analyses of fillet traits in Nile tilapia Oreochromis niloticus. Aquaculture, Amsterdam, v. 356-357, p. 381-390, ago. 2012b.

UNITED NATIONS. Food and agriculture organization fisheries and aquaculture department. The state of world fisheries and aquaculture. Rome: FAO, 2012. 227 p. 